\title{
THE PLIGHT OF GERMAN MISSIONS IN MANDATE CAMEROON: AN HISTORICAL ANALYSIS
}

Lang Michael Kpughe ${ }^{1}$

\section{Introductory Background}

The German annexation of Cameroon in I 884 marked the beginning of the exploitation and Germanization of the territory. While the exploitative German colonial agenda was motivated by economic exigencies at home, the policy of Germanization emerged within the context of national selfimage that was running its course in nineteenth-century Europe. Germany, like other colonial powers, manifested a faulty feeling of what Etim (20I4: I97) describes as a "moral and racial superiority" over Africans. Bringing Africans to the same level of civilization with Europeans, according to European colonial philosophy, required that colonialism be given a civilizing perspective. This civilizing agenda, it should be noted, turned out to be a common goal for both missionaries and colonial governments. Indeed the civilization of Africans was central to governments and mission agencies. It was in this context of baseless cultural arrogance that the missionization of Africa unfolded, with funds and security offered by colonial governments. Clearly, missionaries approved and promoted the pseudo-scientific colonial goal of Europeanizing Africa through the imposition of European culture, religion and philosophy. According to Pawlikova-Vilhanova (2007: 258), Christianity provided access to a Western civilization and culture pattern which was bound to subjugate African society.

There was complicity between colonial governments and missions in the cultural imperialism that coursed in Africa (Woodberry 2008; Strayer I976). By I884 when Germany annexed Cameroon and other territories, the exploitation and civilization of African societies had become a hallmark

I Department of History, University of Bamenda, Bamenda, Cameroon. E-mail: mickpughe@ yahoo.com 
of German colonial policy (Harry I968: 364 ). Achieving this dual objective in Cameroon required collusion between the colonial government and the missions. In fact, justifications for the preference that was given to German missions to missionize in Cameroon were expressed in light of the exigencies of the German nation. At this time, there was a deepening nationalist spirit in Germany with which German missions identified (Ryland 2013). In this context of a nationalist agenda at the forefront of German colonial advocacy came German mission agencies to Cameroon. These German missions were mission agencies born at a time when processes of nationalization of religion and religionization of Germany were running their course. The missionaries employed by missions that emerged in this context were among the intervening actors in the process of the contact between religion and state, characterized by efforts at nation building. So, the missions that were captioned as "German" and that were allowed to carry out mission work in Cameroon were those that were concerned with the building of German nationalism. It is clear that what it took to be ranked a German mission was not just mission agencies with German roots and in the hands of German missionaries. It also concerned missions that accrued from the Protestant Reformation, which as a whole was celebrated as pre-history of the German national unity. Little wonder, there was the identification of the German nation with the history of Protestantism.

During the over thirty years of German colonialism in Cameroon, German mission agencies such as the Basel Mission, German Baptist Mission, German Pallotine Fathers and German Sacred Heart Fathers evangelized in the territory in ways that enhanced the dual colonial agenda of exploitation and pseudo-civilization. On the eve of the First World War which triggered Cameroon's transition from a German colony to a Mandate of the League of Nations, the missions could not be dissociated from the German colonial enterprise. Their neutrality and supranationality which the I9I0 World Missionary Conference at Edinburgh attempted to proclaim had faded. Indeed rival colonial powers, Britain and France especially, understood German missions as natural partners of German colonialism. This was the context in which German missions came to be defined on the eve of the First World War. It was therefore highly likely that during this period that was marked by what Goosen (2010: 27) aptly describes as "missionary imperialism", a war between rival colonial powers could not have allowed the nationalist-oriented German missions indifferent (Haupt 2008). While their nationalism caused them to support the German colonial effort, the Allied Powers saw missionaries as natural targets if complete ascendancy over Germany had to be attained.

Little wonder German missions' property and missionaries were 
targeted by the invading Allied Forces during the I9I4-I9I6 military operations in Cameroon. Sadly, the ecumenical movement that ensued from the Edinburgh Conference lacked the capacity to protect the German missionary enterprise from destruction. But there were efforts at the Paris Peace Conference and in other circles to rescue German missions. This explains why some provisions of the Versailles Treaty and Mandate Agreements were intended to protect these missions from complete destruction. This occurred at a time when Britain and France were chosen as administering powers over the two sections of the partitioned Cameroon and whose duty it was to implement the legal provisions relating to missions. Irrespective of this the two administering powers placed many obstacles on the path of German missions. The Mandate Systems rather turned out to be a period when the foundational work of German missionary enterprise shrank considerably.

Because of the lack of previous research, it is exigent to enrich the literature on German missions in Cameroon by investigating their plight during the Mandate period when the territory enjoyed an international administrative status under the League of Nations (I922-I945). Existing scholarship reveals that too much generalization in church historiography has veiled and obscured some events that had an equally great impact in the history of Christianity. The plight of German missions in mandate Cameroon remains one of such neglected and overlooked areas of Cameroon's church history. Besides, the literature critiquing the Mandate System provides only thin discussions on Cameroon (Pedersen 2006; Wright I930; Logan I928). There are equally general works on Cameroon history having some portions devoted to the mandate period (Abwa 2000; Fanso I989; Ngoh I996; LeVine I968). So far the historiographical debate has more or less omitted the German mission agencies. This paper analyses the Mandate System in Cameroon from a missions' perspective as an effort at filling this scholarly gap.

\section{German Missionary Enterprise in Cameroon: Some History}

Mission work in Cameroon by German mission agencies began shortly after the annexation of the territory in I884. But missionary work in the territory preceded German annexation given that the planting of the Christian faith is traced to the I840s when the English Baptist missionaries began Christianizing the southern region of the would-be Cameroonian territory. In I879 as Efoua (I98I) notes, the English Baptists were joined by the American Presbyterian Mission (APM) whose pioneer missionaries started work among the Bulu. In I884 Germany annexed Cameroon 
and forced the English Baptists to leave the territory probably because of heightened colonial rivalries with Britain and due to the desire to rely on German missions in attaining her civilization colonial agenda. With the exception of the APM, the German Government preferred German missions to work in Cameroon.

Consequently, the pre-war Christian landscape in Cameroon became dominated by German Protestant and Catholic missions. The Basel Mission which was one of such missions replaced the English Baptists in Cameroon in I886 (Werner I969: II; Harry I968: 364). When the Native Baptists left behind by the English Baptists severed links with the Basel Mission in I889, they were placed under the Neuruppine or German Baptist Mission. The latter took over Baptist churches and sent missionaries to Cameroon among them Carl Bender, Paul Gebauer, C. Hofmeister Rhode, Adolf Orther and Herman Kayser. Thanks to these men, the Baptists managed I2 mission stations, 32 schools, Ioo teachers, I60 church buildings and 23 missionaries on the eve of the war (Funteh 2008: 23).

As regards the Catholics, their missionary efforts were represented in Cameroon by the German Pallotine Fathers who began work in the territory in I890 (LeVine I964: 73). In all, the Pallotines had I57,934 faithful, I7,650 catechumens and 19,576 pupils on the eve of the war. This was the outcome of the work carried out by 34 priests, 36 brothers, 29 sisters and about 223 indigenous catechists (Messina \& Slageren 2005: I46-I47). In I9I2, the Sacred Heart Fathers from Germany joined the Pallotines in Cameroon. They were given the task to plant the Catholic faith in the interior of the territory (Ndi 2005). In order to render the work of the Sacred Heart Fathers more evident, the Adamawa Apostolic Prefecture was created in I9I4 and placed under them.

It is clear from the preceding that after 30 years of German imperial rule, missionary work in Cameroon was thriving. Apart from the APM, all the other missions had German origins. These German Protestant and Catholic missions were operating mission stations, schools, health units and provided many other services. By I9I3, for instance, there were 63I mission schools, with 49,000 pupils throughout German Cameroon (LeVine I964: 72). Of course, it was a very fruitful period from the mission perspective as thousands of people had converted to Christianity. It was this strong presence of German missions in Cameroon that pushed some scholars to associate them with German colonialism (Pierard I993: 5). In fact, collusion between missions and the colonial government was to some extent the hallmark of German colonial enterprise. This lends credibility to Strayer's observation that missionaries willingly served colonial regimes (1976). No wonder the Entente Forces characterized German missions as nothing more than an 
"arm of the German colonialism". Accordingly, missions became the target of Allied military operations during the First World War.

\section{World War One and the Question of German Missions' Neutrality}

This section highlights the importance of the First World War in coming to an understanding of the plight of German missions in Cameroon. It deals with and seeks to present explanations as to why the First World War threatened the German missionary enterprise to its very foundation irrespective of growing ecumenism and claims for missions' neutrality and supranationality. In I9I4 war broke out between imperial Germany and a number of other colonial powers. Fought in Cameroon from I9I4 to I9I6, this war resulted in devastating consequences for the German missionary enterprise. For close to two years, the Allied Forces moved through the territory and disrupted mission work by closing mission stations, schools, health services and deporting almost all missionaries working under German missions. By February I9I 6 when military operations folded up, the war had convulsed all aspects of mission work in occupied Cameroon, with some mission property suffering heavy destruction. The war presented a challenge to Catholic and Protestant missions even as they sought to respond to the exigencies of total warfare. Efoua (I98I: 54) observes that almost all missionaries were deported to the Queens Ferry concentration camp from where they were repatriated to their countries of origin. For instance, the Basel Mission station at Sakbayeme was almost completely destroyed during the war, and its debris was used to construct retrenchments. In addition, the Sakbayeme residential home for missionaries was transformed into a fort by the Allied Forces (Messina \& Slageren 2005: 9I).

This dragging into crisis of a missionary movement that had flourished for close to thirty-years at a time of international missionary cooperation and claims of missions' neutrality begs for further analysis. There were two opposing contexts on which the plight of missions hinged: the relationship between missions and German colonialism which was used by Allied Powers as a basis for defining German missions and the new ecumenical movement with its questioned description of missions as neutral and supranational. Germans were caught between their patriotic tendencies that manifested as support for the German colonial enterprise and the required abidance to the ecumenical prescription of neutrality in the mission field. The expectation in German missionary circles was that the international ecumenism and mission cooperation could rescue them from Allied mistreatment. As military operations unfolded, it soon became evident 
that the defining of missions as natural partners of German colonialism was having an edge over their understanding as neutral and supranational, with no loyalty to Germany. As such, Britain and France built on this missions' complicity with German colonialism to subject them to mistreatment in the course of the war. In Cameroon it was a near impossibility to establish a wall of separation between missions and German colonialism, especially its civilizing agenda, despite open claims by missionaries that they did not liaise their work with the spread of Western civilization. In Allied thinking, a German defeat could not be complete without subjugating German mission agencies. Pierard corroborates this thinking, noting that, "As soon as the Allies subdued the colonial possessions, they began rounding up the missionaries who served under the German boards."

It was in vein that German missionaries in Cameroon waited for international missionary solidarity to rescue them from the Allies. The ecumenical spirit that was established at the I9Io Edinburgh Conference had seemingly collapsed when faced with the stresses of the war. Even the Continuation Committee (some of whose members were German missionaries) which was created to continue the promotion of missionary cooperation and to act as guarantor of their protection had ceased to function by I9I7, with no effort to come to the assistance of German missions in Cameroon. Faced with no opposition, the Allies simply overlooked the ecumenical concept of neutrality, claiming that German missions were not supranational. By placing the responsibility for the outbreak of the war on German shoulders, Allies openly accused German missions for their participation in bringing about the war. For the Allies therefore, military assaults on the property of missions and the internment and deportation of missionaries were justified acts in the context of a war in which missionaries were not neutral. Worth noting is the fact that the Allies were backed in their anti-mission actions by their home mission boards. This was enough evidence that missionary solidarity had been shattered by the war as missions belonging to competing colonial powers took sides in a war having a negative imprint on mission work.

A response from German mission circles was expected. In August I9I4, the authorities of the Basel Mission and German Baptist Mission received a manifesto from the German Evangelical Missions Assistance Agency whose goal was to protect German Protestant missions. Signed by twenty-nine German theologians and missionary leaders, the manifesto rejected Allied claims that Germany and its missions were responsible for the outbreak of the war. The manifesto also denounced atrocities on thriving German missions, regretting the absence of an ecumenical spirit in such a trying moment (Pierard). Prompt reactions to this strongly worded manifesto 
came from British and French mission leaders. Apart from supporting the positions taken by their countries on the issue of the First World War, they challenged the neutrality of German missions, arguing that the mistreat to which they were subjected was justified. These counter accusations dragged on as the German missionary enterprise in Cameroon was being ruined. In I9I6 when military operations ended following the defeat and ousting of the Germans, their mission work had been orphaned. There was no single German missionary left in the territory. While waiting for the outcome of the war in Europe, Britain and France partitioned Cameroon, and remained consistent in mistreating German missions. With the end of the war in I918 and preparations for post-war peace talks at Paris, an international crusade was launched to rescue missions from total destruction.

\section{From World War 1 to the Mandates: Legal Perspectives on German Missions}

The end of World War I was a political setting for the creation of the Mandate System by the League of Nations. These events were a cornerstone of post-war arrangements at the Paris Peace Conference, with the question of German missions dragged into the deliberations and final outcomes of the process. In this section, I focus in some depth on the struggle to rescue German missions in Cameroon in a context of post-war arrangements that was marked by a clash between Anglo-French imperial ambitions and a galvanized ecumenical spirit. While Anglo-French imperial goals threatened the continuity of the German missionary enterprise in Cameroon, the rising ecumenism after the end of the war was committed to rescuing German missions from total destruction. Did the pursuance of imperial goals by Britain and France destroy Germans missions in Cameroon or did the ecumenical response offer them protection? The response to this question is found in Anglo-French post-war attitude towards the missions and the ecumenical reaction at a time when peace negotiations were running their course at the Paris Peace Conference.

With the end of military operations in November I9I8 and the almost inexistence of the ecumenical movement, Britain and France brought to the fore their imperial ambitions in Cameroon, which among other things involved efforts at confiscating and annexing the orphaned German mission assets. Both powers even sought to officially terminate the work of these missions and to invite specific nationals to take over. This policy was inherent in imperial thought since they had a burning desire to annex the German territories seized during WWI. In the French section, efforts were made to replace German missions with French ones. The work 
of the German Pallotine Fathers and their property was handed over to the French Holy Ghost missionaries while the Paris Evangelical Mission (PEM) succeeded the Basel Mission and the German Baptist Mission. There was some caution in the British sphere as no expedient action was taken to replace German missions with British ones. It appears Britain wanted that the transition from war to peace should run its course before taking final decisions on the missions. But the prohibition of German missionaries from working in the territory remained. This led to the decline of the Christian communities and the revival of traditional religious practices, specifically secret societies, which missionaries considered as pagan (Werner ig68: 48). In the face of this clerical challenge, Islam was making substantial gains, especially in the Western Grasslands where there were no missionaries.

The above dilemmas facing Germans in Cameroon were similar to what was transpiring in German East Africa, Togoland and German South West Africa. This accounts for the rise of a special ecumenical spirit intended to influence the deliberations at the Paris Peace Conference in view of limiting the damage. The new ecumenical movement was represented by the Emergency Committee of Cooperating Missions (ECCM) which came into existence in I9I8. But during the first months of deliberations at Paris, the weight of the committee was not yet evident given that it was still struggling to gain international recognition. Consequently, statesmen at Paris, based on imperial concerns, resolved to confiscate all foreign properties belonging to German missions and use the proceeds from the sale of these to settle German debts to Allied governments (Pierard i998: I8). Reversing this resolution became the main struggle of the ECCM since its implementation would have meant the total destruction of German mission work. The leaders of the Committee rushed to Paris and worked behind the scenes to reverse the situation. It represented the peak of the clash between imperial concerns and missionary neutrality, with national sentiment edging the ecumenical spirit.

While in Paris, those at the forefront of the ECCM insisted that a clause protecting German missions be added to the Versailles Treaty that was still under preparation. But as Spohn and Sauer (2009) note, the statesmen rather called on German missions to assume their share of responsibility for the outbreak of the war. To Britain and France, the properties of German missions in the former colonies were perceived as the spoils of war to be shared among the victors. By partitioning Cameroon in I916, Britain and France had hoped to annex these territories together with the property of the missions. By this time, representatives of the ECCM had worked from behind the scenes to drag the question of German missions into the political deliberations for post-war international law. The deliberations caused the 
statesmen to review the resolution earlier taken, this time around granting some protection to German missions in the colonies. It is Article 438 of the Versailles Treaty that carries this clause protecting missions. It reads:

The Allied and Associated Powers agree that where Christian religious missions were being maintained by German societies or persons in territory belonging to them, or of which the government is entrusted to them in accordance with the present Treaty, the property which these missions or missionary societies possessed, including that of trading societies whose profits were devoted to the support of missions, shall continue to be devoted to missionary purposes. In order to ensure the due execution of this undertaking the Allied and Associated Governments will hand over such property to boards of trustees appointed by or approved by the Governments and composed of persons holding the faith of the Mission whose property is involved. The Allied and Associated Governments, while continuing to maintain full control as to the individuals by whom the Missions are conducted, will safeguard the interests of such Missions (Treaty of Versailles I9I9).

The foregoing resolution represented a theoretical achievement in the struggle for the survival of the German missionary enterprise in Cameroon and elsewhere. This was disturbing for France and Britain who had already adopted hostile measures towards German missions in Cameroon. It was now their duty to safeguard the interests of such missions by ensuring that there was continuity. It represented a check on the religious imperial ambitions of both powers in Cameroon, and it was hoped that this would bring to an end the post-war assaults on German missions. In a rare moment, the ideal of missionary freedom and neutrality was gaining recognition.

In order to ensure the practical implementation of this clause in the colonies, officials of the ECCM did everything to encourage participants at the Paris Peace Conference to factor such guarantees for missions' protection in the rules and regulations governing the League of Nations mandates. Article 22 of the Covenant of the League of Nations provided among other things that the mandatory should guarantee freedom of conscience and religion on behalf of the League. Regarding Cameroon, Britain and France signed separate mandate agreements with the League. The agreements, in the light of Article 438 of the Versailles Treaty and Article 22 of the Covenant of the League, went further to guarantee the protection of German missions. In both agreements, the article read:

The Mandatory shall ensure in the territory complete freedom of conscience and the exercise of all forms of worship which are consonant with public order and morality; missionaries who are nationals of states members of the League of Nations shall be free to enter the territory 
and to travel and reside therein, to acquire and possess property, to erect religious buildings and to open schools throughout the territory; it being understood, however, that the mandatory shall have the right to exercise such control as may be necessary for the maintenance of public order and good government, and to take all measures required for such control (Rubin I971: 198).

This article of the Mandate Agreement as well as those enshrined in the Versailles Treaty and Covenant of the League therefore provided that British and French colonial mandate authorities should act as protectors of German missions in the two Cameroonian territories placed under their administration. Indeed the Paris Peace Conference and the ensuing League of Nations created an international legal basis for agreement on the protection of German missionary enterprise in the two mandated territories of Cameroon. As such, there was an international law guaranteeing the survival of German missions and whose implementation rested on the shoulders of Britain and France under the supervision of the League. The latter, in I92I, put in place the Permanent Mandate Commission, charged with overseeing this system of international supervision. The ecumenical movement which further gained steam was expected to ensure that the legal protection for the missions achieved during the post-war deliberations was not transgressed by the Mandatories and the League. Whether or not the trio (colonial mandate authorities, League of Nations and the ecumenical movement) acted in defense of German missions, as provided by the above legal parameters, is the focus of the remaining two sections of this paper.

These sections concentrate on the actions undertaken by the Mandatories in the two mandated territories in regard to German missions. The latter's persistent difficulties in spite the existence of a legal protection basis is relevant for an assessment of the Mandate System and its deficiencies. The Mandatories charged with the implementation of the missions' protection laws played a significant role in creating the League of Nations and the Mandate System itself. They went on to express the will to be mandated with the territory of the former German colony Cameroon, which had been partitioned into British and French Cameroons. The League approved the partition and mandated both powers in I922 with the portions of Cameroon they had received in the course of the partition. Existing scholarship reveals that the two mandatory administrations were not clearly distinguishable from colonial administrations (Fanso 1989; Ngoh I996; LeVine 1964). This was expected given that the Mandatories manifested huge colonial desires which they placed above international law. 


\section{German Missions' Treatment in British Cameroon}

In British Cameroon, a final policy towards the German missions had to be adopted from I922 when the Mandate System went operational. In total violation of the legal provisions of the Versailles Treaty, the Covenant of the League of Nations and the Mandate Agreement that were designed to protect Christian missions from the colonial desires of the Mandatories, British mandatory colonial officials adopted the policy of inviting British missionary agencies to replace the German ones (Ndi 2005: 38). Colonial exigencies at the time made Britain not to accept the return of the German missionaries to her sphere, since the fashioning of the Mandate System did not mean the end of colonialism. Matz (2005:50) is right in his observation that the deficiencies of the League of Nations Mandate System cannot be analyzed without building on the colonial realities at that time. Little wonder Matz perceives the Mandate System as an "instrument of imperial power policy" (2005: 50). This context permits us to understand the recourse to British missions to replace German ones in British Cameroon, with the League doing almost nothing to check such gross violation of international law. British colonial mandate authorities in the territory were worried about the possibility of German mission agencies working towards promoting German interest if they were allowed to return. The anti-German missions' policy was also a product of appeals by some traditional rulers (with whom the British were already collaborating) for British missionaries to replace German ones.

The German Sacred Heart Fathers and the Pallotine Fathers both of the Catholic faith tradition were the first victims of the anti-German missions' policy. In a letter to the Colonial Office, Herbert Ruxton in his capacity as Resident requested for a British Catholic Mission to replace the two German Catholic mission agencies. Without any hesitation, the Colonial Office approved the request and its choice fell on the London-based Mill Hill Mission (Ndi 2005: 39). This was followed by talks involving the Colonial Office, Mill Hill Mission and the Vatican in view of obtaining an ecclesiastical clearance. Sadly, the Permanent Mandate Commission and the two German missions that were to be replaced were not part of these negotiations. The laws designed to protect these missions were fragrantly violated. In I922, Mill Hill Missionaries under the leadership of Fr John William Campling effectively replaced the Pallotine and Sacred Heart Missionaries. These English missionaries also inherited the property of their German counterparts. The laws which provided that the Mandatory should protect the interest of German missions and to hand over their property to boards of trustees were overlooked by the British. This illegal 
replacement and property confiscation amounted to a total destruction of the foundational work of German Catholic mission societies in the British sphere of Cameroon. The successful implementation of this imperiallymotivated policy also hinged on the absence of the Catholic missions in the ecumenical movement at the time. So, the efforts of ecumenical gatherings to rescue German missions focused on the Protestant ones that adhered to the ecumenical spirit.

Recourse to British missions to replace German Protestant missions met with fierce ecumenical resistance. British colonial mandate authorities overlooked the neutrality of the Basel and Baptist missions and their legality to pursue mission work in British Cameroon. What followed were efforts for British missions to take over the work and property of German Protestant missions. The remaining Protestant missionaries in the internment camps were repatriated at a time when measures were being taken for British missions to replace German ones. Reverends Rhode and Bender who were seen as obstacles to British imperial mission policies were expelled from the territory in spite the fact that they did not have German roots (Helga I999). The British Baptist Mission was then invited by Resident Ruxton through the Colonial Office to take over the work of the German Baptist Mission. As the English Baptists were preparing to come to Cameroon, the International Missionary Council (IMC) which was created in I921 from the ruins of the ECCM condemned the decision, arguing that it was underpinned by selfish British colonial desires. In I924, during the Conference of Missionary Societies in Europe and America held in Birmingham, obstacles to evangelization in Africa were discussed. The recourse to British missions to replace German ones, especially in Cameroon was denounced. Given that the conference took place in British, its organizers requested the Colonial Office to lift the ban on German missionaries operating in Africa and to stop handing over their property to British missions. In response, the Colonial Office said measures were to be taken to end discrimination against German Protestant missions. This was how the transfer of the works of the German Baptists to the British Baptists was foiled, following the lifting of the restrictions in late I924. In I928, Baptist Missionaries officially returned to British Cameroon, and by I935 they had constituted themselves into the Cameroon Baptist Mission (CBM).

At the same time, there were similar efforts to stop Basel Missionaries from resuming work in the British sphere of Cameroon. The guarantees for missionary freedom enshrined in the regulations governing the League of Nations mandates meant nothing to the British. By I922, all Basel Missionaries had been forced out of Cameroon, with the church abandoned in the hands of indigenous clerics who appealed to the Basel 
Mission to send some of the missionaries back to Cameroon (Werner I969: 58). Since an embargo prohibited German Missionaries from working in Cameroon, the Basel Mission, as Werner (I969: 58) notes, made fruitless negotiations for American Presbyterians to step in. Thus pushed to the wall, Basel Mission authorities took the matter to ecumenical circles. In I923, pressure from the IMC had caused Britain to soften its position. The policy of inviting a British mission to replace the Basel Mission was abandoned. Rather, the British allowed the Basel Mission to continue its work, insisting that only missionaries not having German roots be deployed. So, the Basel Mission, under Swiss missionaries, resumed work in British Cameroon, as the struggle to lift the ban on German missionaries continued.

This struggle was championed by the IMC and missionary advocates. Through their efforts, the British government in I924 lifted the embargo on mission work by German missionaries in its possessions. The Colonial Office and the Resident for British Southern Cameroons then abolished all restrictions which had been placed on the Basel Mission since the war. In December I925 Reverend Adolf Vielhauer arrived in Cameroon from Basel to coordinate Basel Mission work in Cameroon. Through discussions with the Resident in Buea, the Basel Mission received its property back, marking the end of the crisis period. The ensuing freedom of missionizing in the territory was only threatened by the Second World War. During the war, restrictions were placed on German missionaries and they were interned and forcibly deported (Werner I969: 79). They returned only during the Trusteeship period when the passions of war had subsided. These deportations, it should be stressed, violated the missionaries' freedom enshrined in the regulations governing the League of Nations mandates.

While Protestant missions were successful in the struggle to return to British Cameroon, the two German Catholic ones, namely, Pallotine Fathers and Sacred Heart Fathers, did not. The Protestants had benefitted from the ecumenical pressure that was mounted on the British government. By not being part of the ecumenical movement, Catholic missions could only rely on the Vatican. The latter it should be noted lacked the potential to challenge the restrictions on German missions imposed by the British government. By yielding to such a policy irrespective of its violation of international law on missionaries' freedom and protection, the Vatican had colluded with the British in destroying the foundational work of the Pallotine Fathers and Sacred Heart Fathers. Their property was taken over by the Mill Hill Missionaries. There are specific colonial reasons as to why the legal provisions for the protection of German missions were largely transgressed by British colonial mandate authorities. In particular, attention has been drawn to the degermanization policies and civilizing agendas of 
both powers whose attainment could only come at the detriment of the legal provisions of the Mandate System.

\section{Dilemmas in French Cameroon}

In the French mandate of Cameroon, there was no near prospect of German missions being allowed to resume their work. Even missionary dialogue and debate that ensued from the ecumenical movement were not strong enough to cause the French to respect laws governing League of Nations mandates. While pursuing a policy of degermanization directed, in part, towards the elimination of German mission work after the end of the war, French colonial mandate authorities worked towards replacing German missions with French ones. A ban was placed on mission work by German nationals and the properties of their missions were taken over by French societies.

Overlooking all existing agreements, French colonial mandate authorities launched an assault on the loan German Catholic mission (Pallotine Fathers) that was present in French Cameroon. The Holy Ghost Fathers from Paris were invited to replace the German Pallotine Fathers (Messina and Slageren 2005: I53). This was the handiwork of successive colonial administrators such as General Aymerich and Lucien Fourneau who battled hard to replace German missions with French ones. With the effective take off of the Mandate System in 1922, France entered into formal talks with Rome in view of rendering the takeover official. Ensuing from this was the Pope's appointment of French man, Mgr Francois Xavier Vogt as the Apostolic Administrator of Cameroon in I922. This amounted to the total elimination of the German Pallotine Fathers' work in the French mandate of Cameroon. They were never permitted to return to the territory. Although the Vatican was involved in the replacement negotiations, it is clear that the provision of article 22 of the peace treaty granting freedom of work in the mandated territories to German missions was transgressed. Being a largely Catholic state and given its good ties with the Vatican, France destroyed the foundational work of German Catholic missions, overlooking the freedom of mission work provisions enshrined in the Mandate Agreement.

Concerning the two German Protestant missions in French Cameroon, namely, the Basel Mission and German Baptist Mission, their work was taken over by the Paris Evangelical Mission. On their arrival, the French Protestants were given the freedom to take control over the totality of the properties left behind by the Basel and Baptist Missionaries. In fact, the mission stations, schools, church buildings and thousands of Christians that were under the charge of the German Protestant missions 
were in total illegality transferred to the Paris Evangelical Mission by French colonial mandate authorities. The provision of Article 348 requiring that the properties which the German missions possessed be placed under a board of trustees was fragrantly violated. This policy of replacing German missions with French ones also went against Article 7 of the Mandate Agreement which made it mandatory on the French mandate colonial authorities to ensure that missionaries were accorded the freedom to carry out mission work in the territory. Rather, German Protestant missionaries were denied entry into French Cameroon; a policy that caused the German Protestant missionary enterprise to collapse.

Without doubt, the French colonial administrators in Cameroon had allowed their national passions to rise above the concern to ensure the continuity of German mission work. The nationalism, materialism and the pursuance of imperial desires which characterized the French mandate administration combined to produce an anti-German missions' agenda. Little wonder the neutrality of these missions claimed by the ecumenical movement was overlooked by the French who argued that missionaries could not be dissociated from German colonialism. In fact, the dismantling of German mission work in French Cameroon was the handiwork of Commissioner Jules Gaston Carde who headed the mandate administration from I9I9 to I923 (Abwa 2000). This degermanization of mission work was continued from I923 to I933 by Theodore Paul Marchand. Throughout the territory, French became the official language through which mission work was conducted, thus reinforcing the ban on German missionaries to return to the territory.

The ecumenical ideal, in spite its growth and ensuing gatherings, lacked the capacity to check French destruction of the foundational work of German missions. It is important to note that the two French missions (Holy Ghost Fathers and Paris Evangelical Mission) that replaced the German missions were not yet part of the ecumenical movement. Their collusion with the French government in the destruction of German mission work at a time of growing ecumenism is not in doubt. The authorities of these French missions cannot claim that they were not aware of Article 438 of the Versailles Treaty, Article 22 of the Covenant of the League of Nations and Article 7 of the Mandate Agreement. They worked closely with their government in violating these legal provisions that were framed with the intent of protecting German missions.

The League of Nations whose role it was to ensure that these legal provisions were strictly respected certainly failed to do its job. As a matter of fact, the League was indifferent to the French ruining of the German missionary enterprise. Given their volatility to unlawful French colonial 
desires and considering the limitations of the ecumenical movement, German clerics expected the League of Nations, especially its Mandate Commission, to rally behind them in the defense of their neutrality and supranational status. But the League had been brought under the dominance of imperial powers that were concerned with the defense of their harmful nationalism ideologies, even if this did not conform to the vision and mission of the League. In French thinking at the time, as Kissinger (I994: 235) rightly observes, the main purpose of the League of Nations was to work against German interest, not to promote it. France was in a position of political, military, economic and social vulnerability in the context of two successive humiliating defeats inflicted by Germany. The latter, no doubt, was not in the good books of France, and limiting Germany's expansion in all spheres was a core French goal. The neutrality of the German missions and the legal instruments for their protection therefore meant nothing to French colonial mandate authorities.

The League, under the heavy weight of French influence, could not defend the interest of German missions placed under French administration. Rightly therefore, Susan Pedersen (2006: 560) observes that "mandatory administrations were not distinguishable from colonial administrations." This historian refuses to see the Mandate System as "a system of governance", on the basis of its flaws. If one should go by the complicity of the Mandate System authorities, especially the Mandate Commission, to the total destruction of German missions in French Cameroon, then the conclusion by Mandate System scholars that the system was merely a disguised form of imperial annexation is tenable. The French mandate administration, as Cameroon history scholars concluded in their separate studies, was not different from French colonial administration in its colonies (Abwa 2000; LeVine I964; Fanso I989; Ngoh I996). In his massive study on mandate and trusteeship French Cameroon, Daniel Abwa (2000: 95) insists that French policy was tailored towards francisizing the territory by replacing German aspects with French ones. The Mandate Commission could not prevent this from happening. In the thinking of Pedersen (2006: 565 ), the Commission could do very little about the oversight of Mandatory powers. It could only denounce without taking action. The initial absence of a German representative in the Commission made this overlooking of the interest of German missions to progress without any formal condemnation from the Commission. Expectedly, German mission work had shrunk on the eve of World War 2 with no hope of restoration. 


\section{Conclusion}

The post-World War I peace treaties and the ensuing League of Nations alongside its Mandate System provided legal instruments for the protection of the interest of German mission work in the mandated territories. In the British and French mandates of Cameroon, both mandate administrations were expected to conform to the agreements signed by the two mandatories with the League. One provision of the agreements (Article 7) guaranteed freedom of mission work, including German missions. The colonial mandate administrations in the two territories overlooked these legal instruments and opted for policies that were detrimental to the German missions. There was the recourse to British and French mission agencies to replace German ones, with little or no objection from the League. The provisions of the mandate system relating to missions were hypocritical. German missions in Cameroon were assigned to Britain and France with a mandate under League supervision, to ensure their protection and sustenance. What that meant was ambiguous, given that a provision of Article 438 prohibited mission work by German nationals. Building on this ambiguity and their colonial ambitions, British and French colonial mandate authorities shattered the foundation of German missions.

While the totality of German mission work was terminated in French Cameroon, the British limited the hostility only to Catholic missions as the mission work of Protestant missions was restored in the I920s. Clearly, the mission endeavor by German missionaries in both territories suffered enormously in a context of a complacent League, a non inclusive and weak ecumenical movement and the pursuance of imperial desires by the two Mandatories. Consequently German missionaries' ambition to establish self-governing, self-supporting and self-propagating churches in Cameroon suffered mightily. Only the Basel Mission and Baptist missionaries were able to establish the Presbyterian Church in Cameroon and the Cameroon Baptist Convention respectively in the British sphere. The efforts of the other missions ended in total failure, as the triple mission agenda was continued by British and French mission agencies. This study therefore adds to the body of literature critiquing the Mandate System. It has used the question of German missions as a case study to support the scholarly stance that the mandate system was a disguised form of imperial annexation. 


\section{REFERENCES}

Abwa, Daniel. 2000. Commissaires et Hauts-Commissaires de la France au Cameroun (1916-1960): Ces Hommes qui ont Façonné Politiquement le Cameroun. (2e Edition). Yaounde: Presses Universitaires de Yaounde.

Efoua, Samuel Mbozo’o. I98I. “La Mission Presbytérienne Américaine et les Mutations Religieuses et Sociales Chez les Peuples du Sud-Cameroun (I9I9-I939)". Thèse de Doctorat ze Cycle D'Histoire, Université Jean Moulin-Lyon III.

Etim E. Okon. 20I4. "Christian Missionaries and Colonial Rule in Africa: Objective and Contemporary Analysis". European Scientific Journal IO (I7): I92-2009.

Fanso, V. G. 1989. Cameroon History for Secondary Schools and Colleges, Vol. 2, The Colonial and Post Colonial Periods. London: Macmillan Publishers.

Funteh, M. B. 2008. "Intra-Cameroon Baptist Convention Conflicts I9542002: A Historical Investigation”. Ph.D. Thesis, University of Yaounde I.

Harry, R. I968. Germans in the Cameroons 1884-1914: A Case Study in Modern Imperialism. New York: Greenwood Press.

Helga Henry Bender. I999. Cameroon on a Clear Day: A Pioneer Missionary in Colonial Africa. Pasadena: William Carey Library.

Kissinger, Henry. I994. Diplomacy. New York: Simon \& Schuster.

LeVine, V. T. I964. The Cameroons from Mandate to Independence. Los Angeles: University of California Press.

Logan, Rayford. I928. "The Operation of the Mandates System in Africa". Journal of Negro History I3 (4): 423-477.

Matz, Nele. 2005. "Civilization and the Mandate System under the League of Nations as Origin of Trusteeship". In: A. von Bogdandy and R. Wolfrum, eds. Max Planck Yearbook of United Nations Law. Volume 9. Netherlands: Koninklijke Brill N. V., 47-95.

Messina, Jean-Paul et Jaap Slageren 2005. Histoire du Christianisme au Cameroun: Des Origines a Nos Jours. Paris et Yaoundé : Editions Karthala et Editions Cle.

Ndi, A. 2005. Mill Hill Missionaries in Southern West Cameroon 1922-1972: Prime Partners in Nation Building,. Nairobi: Paulines Publications Africa. 
Ndi, Richard Tantoh 2012. "The Processes of Integration and Affiliation in the Cameroon Baptist Convention (CBC) I954-2004". PhD Thesis, University of Yaounde I.

Ngoh, V. G. 1996. History of Cameroon Since 1800. Limbe: Presbook.

Pawlikova-Vilhanova, Viera. 2007. "Christian Missions in Africa and their role in the transformation of African Societies". Asian and African Studies I6 (2): 249-260.

Pedersen, Susan. 2006. "The Meaning of the Mandates System: An Argument". Geschichte und Gesellschaft 32 (4): 560-82.

Rubin, Neville. I97I. Cameroon: An African Federation. London: Pall Mall Press.

Ryland, Glen P. 2013. "Translating Africa for Germans: The Rhenish Mission in Southwest Africa, I829-I936". PhD Thesis, University of Notre Dame.

Spohn, E. and Sauer, C. 2009. "War Zeal, Nationalism and Unity in Christ: Evangelical Missions in Germany during World War I”. Studia Historiae Ecclesiasticae.

Strayer, Robert. I976. "Mission History in Africa: New Perspectives on an Encounter". African Studies Review I9 (I): I-I5, http://www.jstor.org, Accessed on 2 July 2014.

Werner, K. I969. The History of the Presbyterian Church in West Cameroon. Victoria: Presbook.

Woodberry, Robert D. 2008. "How do we Deal with the Baggage of the Past? Reclaiming the M-Word: The Legacy of Missions in Non-Western Societies". International Journal of Frontier Missiology 25 (I): I7-23.

Wright, Quincy. I930. Mandates under the League of Nations. Chicago: University of Chicago Press. 


\section{ABSTRACT}

The First World War and its resultant Mandate and Trusteeship systems greatly affected the German mission enterprise in Cameroon. Apart from causing the forceful ousting of German missionaries from Cameroon, the British and the French whom the League of Nations and United Nations successively chose as administering powers within the Mandate and Trusteeship frameworks adopted hostile policies towards German missions. From the beginning of the war to the post-Second World War era, the foundation of German missions was seriously threatened. This paper critically examines the treatment of German missions in both British and French Cameroons during the Mandate and Trusteeship periods, focusing especially on the opposing attitudes of both administering powers towards the missions in their spheres of influence. The paper establishes that the administering powers' treatment of German missions, which was underpinned by imperial and nationalist exigencies, roiled the attainment of the triple missionization agenda of planting self-supporting, self-governing and self-evangelizing churches. It thus argues that the First World War triggered the mistreatment of German missions, with some missions forced to terminate their activities while others were allowed to continue their mission work under difficult conditions.

\section{KEYWORDS}

Cameroon; First World War; German Missions; Second World War; Mandate System; Trusteeship System. 